\title{
PERBAIKAN SIKAP KERJA \\ DAN PENAMBAHAN PENERANGAN LOKAL \\ PADA PROSES PEMBUBUTAN MENURUNKAN KELUHAN \\ MUSKULOSKELETAL, KELELAHAN MATA DAN MENINGKATKAN \\ KETELITIAN HASIL KERJA MAHASISWA DI BENGKEL MEKANIK POLITEKNIK NEGERI BALI
}

\author{
I Gede Oka Pujihadi; I Putu Gede Adiatmika; I Ketut Tirtayasa \\ Program Studi Magister Ergonomi Fisiologi Kerja, Program Pascasarjana, \\ Universitas Udayana
}

\begin{abstract}
ABSTRAK
Praktikum pembubutan dilakukan dengan posisi berdiri. Selama proses membubut tidak disediakan bangku untuk duduk. Praktek pembubutan juga terkadang memerlukan sikap kerja membungkuk untuk melihat lebih teliti atau memperbaiki peralatan yang ada. Di samping itu tidak adanya penerangan lokal pada mesin bubut menyebabkan tingkat ketelitian mahasiswa dalam membaca skala pengukuran menjadi kurang. Hal ini menyebabkan keluhan pada sistem musculoskeletal, kelelahan pada mata, dan penurunan ketelitian sehingga diperlukan intervensi ergonomi berupa perbaikan sikap kerja dan penambahan penerangan lokal.

Penelitian ini dilakukan secara eksperimental menggunakan rancangan sama subjek melibatkan 15 orang sampel penelitian. Subjek mendapatkan dua perlakuan, Periode I melakukan pembubutan dengan menggunakan cara lama, Periode II menggunakan cara baru dengan intervensi ergonomi berupa perubahan sikap kerja dan penambahan penerangan lokal.

Hasil analisis menunjukkan bahwa terjadi penurunan yang signifikan pada keluhan muskuloskeletal; pada Periode I rerata skor $81,41 \pm 1,80$ sedangkan Periode II dengan rerata skor 65,74 $\pm 3,08$ atau menurun sebesar $19,3 \%(p<0,05)$. Juga terjadi penurunan yang sinifikan pada kelelahan mata; Periode I dengan skor $31,41 \pm 1,78$ sedangkan Periode II dengan skor 16,89 $\pm 2,32$ atau menurun sebesar $46,2 \%(\mathrm{p}<0,05)$. Terjadi peningkatan yang signifikan terhadap ketelitian hasil kerja pada Periode I dengan nilai bias $1,29 \pm 0,45 \mathrm{~cm}$ dan Periode II dengan nilai bias $0,56 \pm 0,15 \mathrm{~cm}$ atau peningkatan ketelitian sebesar $56,9 \%(\mathrm{p}<0,05)$.

Dari hasil penelitian, disimpulkan bahwa (a) Perbaikan sikap kerja dan penambahan penerangan lokal pada proses pembubutan dapat menurunkan keluhan muskuloskeletal mahasiswa di bengkel mekanik Politeknik Negeri Bali, (b) Perbaikan sikap kerja dan penambahan penerangan lokal pada proses pembubutan dapat menurunkan kelelahan mata mahasiswa di bengkel mekanik Politeknik Negeri Bali, (c) Perbaikan sikap kerja dan penambahan penerangan lokal pada proses pembubutan dapat meningkatkan ketelitian hasil kerja mahasiswa di bengkel mekanik Politeknik Negeri Bali.
\end{abstract}

Kata Kunci: Perbaikan sikap kerja, penerangan lokal, keluhan muskuloskeletal, kelelahan mata, ketelitian hasil kerja. 


\title{
ABSTRACT \\ IMPROVEMENT IN WORKING POSTURE AND ADDITION SITE LIGHTING OF TURNING PROCESS REDUCE MUSCULOSKELETAL DISORDER, EYE STRAIN AND IMPROVE WORK ACCURACY OF MECHANICAL WORKSHOP STUDENTS OF BALI STATE POLYTECHNIC
}

\author{
I Gede Oka Pujihadi; I Putu Gede Adiatmika; I Ketut Tirtayasa
}

Practice of turning is done in a standing posture. During the process of turning benches are not provided for sitting. In turning Practice sometimes also requires bending forward working posture to look more carefully or repair existing equipment. Besides, the lack of site lighting on the lathe machine can reduce accuracy level of students in reading measurement scale. This leads to disorder on musculoskeletal system and eye strain; therefore it is necessary to apply ergonomics in terms of improvement in working posture and the addition of site lighting.

The research was carried out experimentally using treatment by subject design; the study sample included 15 people. Subjects obtained the two treatments, period I the turning used the old way. Period II used a new way of ergonomic interventions in the form of improvement in working posture and the addition of site lighting.

The analysis showed that there was significant difference $(\mathrm{p}<0.05)$ on the musculoskeletal disorder, the period I with a mean score of $81.41+1.80$ and at period II with a mean score of $65.74+3.08$ or decreased by $19.3 \%$. There was significant difference in eye strain period I with a score of $31.41+1.78$ and period II with a score of $16.89+2.32$ or decreased by $46.2 \%$ and there was significant difference in the accuracy of the work, period I with a bias score of $1.29+0.45 \mathrm{~cm}$ and period II with a bias score of $0.56+0.15 \mathrm{~cm}$ or increased accuracy of $56.9 \%$.

It is concluded that (a) the improvement of working posture and addition of site lighting in turning process can reduce musculoskeletal disorder of students in mechanical workshop of Bali State Polytechnics, (b) the improvement of working posture and addition of site lighting turning process can reduce eye strain of students in mechanical workshop of Bali State Polytechnic, (c) the improvement of working posture and addition of site lighting in turning process can improve the accuracy of the work of students in Bali State Polytechnic mechanical workshop.

Keywords: Improvement in working posture, site lighting, musculoskeletal disorder (MSD's), eye strain, accuracy of work 


\section{LATAR BELAKANG}

Politeknik Negeri Bali adalah lembaga yang menyelenggarakan pendidikan vokasional. Lulusan politeknik diharapkan sudah siap kerja sesuai dengan kompetensi yang dibutuhkan oleh dunia kerja. Ada beberapa jurusan di Politeknik Negeri Bali, salah satunya adalah Jurusan Teknik Mesin. Upaya penumbuhan kompetensi di Jurusan Teknik Mesin dilakukan dengan beberapa mata kuliah praktikum seperti praktikum pembubutan.

Pembubutan adalah salah satu praktikum yang harus ditempuh oleh mahasiswa Jurusan Teknik Mesin Politeknik Negeri Bali dalam mata kuliah Praktek Permesinan, Praktek Kerja Las dan Praktek Kerja Bangku dan Plat. Mata kuliah ini diberikan pada mahasiswa semester I, II dan III (Jurusan Teknik Mesin, 2008).
Praktikum pembubutan dilakukan di bengkel laboratorium mekanik kampus Politeknik Negeri Bali (Tim Lab Mekanik, 2009).

Praktikum pembubutan dilakukan dengan sikap berdiri dan tidak diperkenankan untuk duduk karena memang pengerjaannya harus dilakukan dengan cara berdiri. Selama proses membubut tidak disediakan bangku atau kursi untuk duduk. Praktikum ini dilakukan dari pukul 08.00 WITA sampai dengan pukul 15.00 WITA dengan istirahat selama 1 jam pada pukul 11.00 WITA sampai dengan pukul 12.00 WITA. Ini berarti mahasiswa berada dalam sikap kerja berdiri selama $2 \mathrm{x}$ 3 jam setiap kali praktikum dengan istirahat satu jam.

Selain sikap kerja berdiri statis, praktek pembubutan juga terkadang memerlukan sikap kerja 
membungkuk untuk melihat lebih teliti atau memperbaiki peralatan yang ada. Hal ini akan mempengaruhi kualitas kesehatan mahasiswa yaitu menyebabkan terjadinya keluhan muskuloskeletal pada para mahasiswa, terutama keluhan bagian punggung dan bahu.

Di samping itu tidak adanya penerangan lokal pada mesin bubut meskipun telah disediakan tempat untuk pemasangan lampu yang menjadi satu dengan mesin bubut. Hal ini menyebabkan tingkat ketelitian mahasiswa dalam membaca skala pengukuran menjadi kurang, sehingga untuk lebih teliti dalam membaca diperlukan sikap membungkuk. Akibatnya kecepatan kerja menjadi terasa lamban, ketelitian menjadi kurang. Selain itu juga menyebabkan kelelahan pada mata, karena harus berakomodasi terus menerus, sehingga perlu intervensi untuk memberikan solusi terhadap permasalahan mahasiswa praktikum ini.

Untuk mengatasi permasalahan di atas dan untuk meningkatkan kualitas kesehatan serta hasil belajar mahasiswa, diperlukan intervensi/aplikasi ergonomi berupa perubahan sikap kerja dari berdiri statis menjadi duduk dan berdiri secara dinamis dan penambahan lampu lokal pada mesin bubut yang dapat diarahkan secara langsung pada objek kerja namun tidak menyebabkan silau. Oleh karena itu dipandang perlu melakukan penelitian tentang aplikasi ergonomi ini pada praktikum pembubutan untuk meningkatkan kualitas kesehatan dan hasil belajar mahasiswa di Bengkel Mekanik Politeknik Negeri Bali. 
Bertitik tolak dari latar belakang masalah tersebut di atas dapat dibuat rumusan masalah sebagai berikut:

1. Apakah perbaikan sikap kerja dan penambahan penerangan lokal pada proses pembubutan dapat menurunkan keluhan muskuloskeletal mahasiswa di bengkel mekanik Politeknik Negeri Bali?

2. Apakah perbaikan sikap kerja dan penambahan penerangan lokal pada proses pembubutan dapat menurunkan kelelahan mata mahasiswa di bengkel mekanik Politeknik Negeri Bali?

3. Apakah perbaikan sikap kerja dan penambahan penerangan lokal pada proses pembubutan dapat meningkatkan ketelitian hasil kerja mahasiswa di bengkel mekanik Politeknik Negeri Bali?

\section{MATERI DAN METODE}

Penelitian ini adalah penelitian eksperimental menggunakan rancangan sama subjek (treatment by subjects design) di mana semua sampel mengalami aktivitas dua periode dalam waktu yang berbeda, diantara periode diberikan washing out untuk menghilangkan efek perlakuan pertama terhadap perlakuan berikutnya. Periode I adalah periode penelitian dimana kelompok sampel melakukan kegiatan praktikum dengan sikap kerja yang lama tanpa penerangan lokal. Periode II adalah periode penelitian dimana kelompok sampel melakukan kegiatan 
praktikum dengan sikap kerja yang baru ditambah dengan penerangan lokal.

Keluhan muskuloskeletal
didata dengan menggunakan
kuesioner Nordic Body Map dengan
empat skala Likert. Kelelahan mata
didata dengan menggunakan
kuesioner kelelahan mata dengan
lima skala Likert. Sedangkan
Ketelitian hasil kerja diukur
menggunakan jangka sorong,
kemudian ditentukan besar
penyimpangan ukuran hasil kerja
terhadap ukuran hasil kerja yang
telah ditetapkan. Semakin kecil
penyimpangannya akan berarti
semakin teliti. Penilaian ketelitian ini
dilakukan oleh instruktur/dosen
pembina praktikum.

Data yang telah diperoleh selanjutnya diolah dan dianalisis dengan bantuan komputer program
SPSS versi 15.0 for windows. Uji kemaknaan data ketelitian sebelum dan sesudah intervensi digunakan uji statistik parametrik t-paired dengan taraf kemaknaan 5\% ( $\alpha=0,05)$. Untuk data keluhan muskuloskeletal dan kelelahan mata, karena data berbentuk skor (nominal) maka uji beda kemaknaan sebelum dan sesudah intervensi ergonomi diuji dengan Wilcoxon test dengan tingkat kemaknaan 5\%.

III. HASIL DAN PEMBAHASAN

\subsection{Kondisi Subjek}

Jumlah sampel dalam penelitian ini adalah 15 mahasiswa. Kelima belas mahasiswa tersebut melakukan aktivitas pada kondisi sebelum dan setelah intervensi ergonomi. Hasil analisis deskriptif terhadap data karakteristik subjek meliputi umur, berat badan, tinggi 
badan dan pengalaman kerja disajikan pada Tabel 3.1 berikut.

Tabel 3.1

Data Karakteristik Subjek Penelitian $(n=15)$

\begin{tabular}{clccr}
\hline No & \multicolumn{1}{c}{ Variabel } & Rerata & SB & \multicolumn{1}{c}{ Rentangan } \\
\hline 1 & Umur (th) & 19,1 & 0,9 & $18,0-20,0$ \\
2 & Berat badan $(\mathrm{kg})$ & 57,5 & 2,6 & $55,0-65,5$ \\
3 & Tinggi badan $(\mathrm{cm})$ & 165,7 & 1,2 & $163,0-168,0$ \\
4 & IMT $\left(\mathrm{kg} / \mathrm{m}^{2}\right)$ & 20,9 & 0,8 & $20,2-23,6$ \\
\hline \multicolumn{2}{c}{ Keterangan : IMT : Indeks Massa Tubuh; SB : Simpang baku }
\end{tabular}

3.2 Analisis Keluhan kondisi awal tidak berbeda secara

Muskuloskeletal

Sebelum dilakukan uji

kemaknaan karena efek perlakuan

perlu dilihat terlebih dahulu

komparabilitas kondisi awal untuk

keluhan muskuloskeletal mahasiswa

praktikan. Kondisi awal (pre) didapat

$\mathrm{p}>0,05$. Hal ini menandakan bahwa signifikan dan bisa dianggap sama.

Efek perlakuan terhadap

keluhan muskuloskeletal dianalisis

dengan melakukan uji beda

kemaknaan pada masing-masing perlakuan yang diberikan. Uji beda kemaknaan ini dilakukan dengan menggunakan Wilcoxon test. Hasil analisis uji beda kemaknaan dapat dilihat pada Tabel 3.2 berikut.

Tabel 3.2

Hasil Analisis Keluhan Muskuloskeletal setelah bekerja (post)

\begin{tabular}{ccccccc}
\hline Subjek & $\mathrm{n}$ & $\begin{array}{c}\text { Rerata skor } \\
\text { keluhan otot }\end{array}$ & $\begin{array}{c}\text { Simpang } \\
\text { Baku }\end{array}$ & $\begin{array}{c}\text { Beda } \\
\text { rerata }\end{array}$ & $\mathrm{Z}$ & $\mathrm{p}$ \\
\hline \hline Periode I & 15 & 81,41 & 1,80 & & & \\
Periode II & 15 & 65,74 & 3,08 & & & \\
\hline
\end{tabular}


Dari Tabel 3.5 dapat Kondisi awal (pre) didapat $\mathrm{p}>0,05$.

dinyatakan bahwa kondisi akhir Hal ini memandakan bahwa kondisi (post) untuk keluhan muskuloskeletal awal tidak berbeda secara signifikan didapat $\mathrm{p}<0,05$. Hal ini menandakan dan bisa dianggap sama.

bahwa terjadi penurunan

Efek perlakuan terhadap muskuloskeletal $(\mathrm{p}<0,05)$.

kelelahan mata dianalisis dengan melakukan uji beda kemaknaan pada

\subsection{Analisis Kelelahan Mata}

masing-masing perlakuan yang Sebelum dilakukan uji diberikan. Uji beda kemaknaan ini kemaknaan karena efek perlakuan dilakukan dengan menggunakan perlu dilihat terlebih dahulu Wilcoxon test. Hasil analisis uji beda komparabilitas kondisi awal untuk kemaknaan dapat dilihat pada Tabel kelelahan mata mahasiswa praktikan. $\quad 3.3$ berikut.

Tabel 3.3 Hasil Analisis kelelahan mata

\begin{tabular}{|c|c|c|c|c|c|c|}
\hline Subjek & $\mathrm{n}$ & $\begin{array}{c}\text { Rerata Skor } \\
\text { Kelelahan } \\
\text { Mata } \\
\end{array}$ & $\begin{array}{c}\text { Simpang } \\
\text { Baku }\end{array}$ & $\begin{array}{l}\text { Beda } \\
\text { rerata }\end{array}$ & Z & $\mathrm{p}$ \\
\hline Periode I & 15 & 31,41 & 1,78 & \multirow[b]{2}{*}{14,52} & \multirow[b]{2}{*}{$-3,408$} & \multirow[b]{2}{*}{0,001} \\
\hline Periode II & 15 & 16,89 & 2,32 & & & \\
\hline
\end{tabular}

\section{Dari Tabel 3.3 dapat}

dinyatakan bahwa kondisi akhir

(post) untuk kelelahan mata didapat

$\mathrm{p}<0,05$. Hal ini menandakan bahwa terjadi penurunan kelelahan mata $(p<0,05)$.

\subsection{Analisis Ketelitian}

Ketelitian ini didata pada setiap produk hasil kerja. Hasil kerja diukur dimensinya dengan 
menggunakan alat ukur Penilaian ketelitian ini dilakukan mikrometer/jangka sorong dan oleh tim dosen pembimbing dicocokkan dengan dimensi yang praktikum. Data ketelitian yang telah ditugaskan. Hasil ukur diperoleh dalam penelitian ini diuji dibandingkan dengan ukuran yang normalitasnya dengan One-Sample sudah ditetapkan oleh Kolmogorov-Smirnov Test. Dari hasil instruktur/dosen pembina praktikum uji normalitas tersebut diperoleh kemudian diambil selisih antara hasil bahwa data ketelitian berdistribusi ukur dengan ukuran yang telah normal $\quad(\mathrm{p}>0,05)$ Analisis ditetapkan oleh instruktur/dosen kemaknaan data ketelitian antara pembina praktikum, semakin kecil Periode I dan Periode II dilakukan selisihnya maka semakin tinggi nilai dengan uji t-paired dan disajikan ketelitian hasil kerja mahasiswa. pada Tabel 3.4 berikut.

Tabel 3.4 Hasil Analisis Data Ketelitian

\begin{tabular}{cccccccc}
\hline Subjek & $\mathrm{n}$ & $\begin{array}{c}\text { Rerata } \\
\text { ketelitian } \\
(\mathrm{cm})\end{array}$ & $\begin{array}{c}\text { Simpang } \\
\text { Baku }\end{array}$ & $\begin{array}{c}\text { Beda } \\
\text { rerata }\end{array}$ & $\mathrm{t}$ & $\mathrm{p}$ \\
\hline \hline Periode I & 15 & 1,29 & 0,45 & 0,73 & 7,100 & 0,001 \\
Periode II & 15 & 0,56 & 0,15 & & & & \\
\hline
\end{tabular}

Dari Tabel 3.4 dapat

dinyatakan bahwa hasil analisis data ketelitian didapat hasil $\mathrm{p}<0,05$. Hal ini menandakan bahwa terjadi peningkatan ketelitian $(\mathrm{p}<0,05)$. Pada Periode I diperoleh rerata ketelitian diperoleh rerata $1,29 \mathrm{~cm}$ artinya ketelitian mahasiswa pada Periode II lebih baik dibandingkan pada Periode I karena memberikan nilai selisih yang lebih kecil. 


\section{Pembahasan}

Umur subjek yang menjadi sampel dalam penelitian ini antara 18

- 20 tahun dengan rerata $19,1 \pm 0,9$ tahun. Rentang umur ini merupakan rentang umur dalam kategori produktif di usia masa kuliah. Pada umur ini subjek bisa melakukan aktivitas dengan kekuatan fisik yang optimal, dan otak yang bisa diasah. Penelitian yang dilakukan Susetyo dkk. (2012) juga mengambil sampel penelitian pada umur produktif yaitu 19-32 tahun.

Keluhan muskuloskeletal diprediksi berdasarkan kuesioner Nordic Body Map. Berdasarkan hasil kuesioner, keluhan muskuloskeletal yang dialami para praktikan sering terjadi pada bagian leher, punggung, pinggang, kedua lutut dan betis, serta keluhan kelelahan pada mata. Hal ini disebabkan oleh sikap kerja berdiri dan terkadang membungkuk ketika praktikum dan penerangan yang kurang karena praktek pembubutan memerlukan ketelitian yang cukup tinggi. Untuk mengurangi keluhan tersebut, dalam penelitian ini dilakukan intervensi berupa penambahan kursi kerja yang didesain khusus agar para praktikan bisa duduk berdiri, dan penambahan lampu penerangan lokal. Hasil analisis menunjukkan bahwa setelah menggunakan kursi dan lampu penerangan lokal terjadi perbedaan yang bermakna $(p<0,05)$ dan terjadi penurunan keluhan muskuloskeletal dari subjek pada Periode I terhadap subjek pada Periode II. Pada Periode I rerata skor 81,41 menjadi 65,74 atau menurun sebesar 19,3\%. Penurunan keluhan muskuloskeletal pada Periode II diprediksi karena penambahan kursi duduk berdiri 
yang digunakan oleh praktikan. dan kelelahan dapat diturunkan Praktikan bisa duduk berdiri pada secara signifikan $(\mathrm{p}<0,05)$ pada kursi ketika melakukan pekerjaan, subjek dengan melakukan perbaikan dan sewaktu-waktu juga bisa berdiri pada stasiun kerja dan sikap kerja sesuai kebutuhan, sehingga keluhan otot yang mungkin terjadi pada leher, bahu, kaki, betis dan yang lainnya bisa berkurang.

Sejalan dengan apa yang dinyatakan Ruccer dan Sunnel (2002) terhadap para dokter gigi, mereka menyatakan bahwa posisi praktek yang salah dalam bekerja terlebih lagi dalam menggunakan perlatan pompa akan menyebabkan gangguan muskuloskeletal. Keadaan ini dapat ditanggulangi dengan melakukan perubahan sikap kerja yang tidak alamiah menjadi alamiah.

Sutajaya dan Citrawathi (2000), Petrus dan Rina (2012) juga menyatakan bahwa keluhan subjektif berupa gangguan muskuloskeletal yang lebih ergonomis.

Analisis kemaknaan dengan uji t-paired menunjukkan bahwa kedua kelompok sebelum melakukan praktikum, rerata kelelahannya tidak berbeda secara bermakna $(p>0,05)$. Sedangkan sesudah melakukan praktikum didapatkan bahwa rerata skor kelelahan mata pada Periode I adalah $31,41 \pm 1,78$ dan pada Periode II adalah 16,89 \pm 2,32. Analisis kemaknaan dengan uji $t$ paired menunjukkan bahwa terjadi perbedaan bermakna $(p<0,05)$ pada kedua periode sesudah melakukan praktikum. Dilihat dari nilai reratanya, terjadi penurunan skor kelelahan mata dari Periode I dengan 
Periode II yaitu dari 31,41 menjadi

16,89 atau menurun sebesar $46,2 \%$.

Adanya keluhan kelelahan

mata pada Periode I disebabkan

karena lampu penerangan yang

kurang memadai, dengan rerata

225,26 lux, sedangkan untuk

pekerjaan yang memerlukan

ketelitian diperlukan intensitas

cahaya sebesar 300-700 lux.

Penurunan skor kelelahan mata

disebabkan oleh implementasi

ergonomi yang diterapkan pada

Periode II. Implementasi tersebut

adalah penambahan lampu

penerangan lokal pada objek kerja.

Setelah diberikan penambahan lampu

penerangan terjadi penurunan skor

kelelahan mata sebesar 46,2\%. Hal

ini diprediksi terjadi bahwa ada

pengurangan akomodasi mata saat

melihat objek kerja, pengurangan

penggunaan energi pada otot mata, dan dapat melihat objek kerja lebih baik.

Pada proses penilaian ketelitian, rerata ketelitian pada Periode I adalah 1,29 $\mathrm{cm}$ sedangkan pada Periode II adalah $0,56 \mathrm{~cm}$, penurunan hasil ini artinya bahwa selisih nilai pada Periode II lebih kecil dari pada selisih nilai pada Periode I dari 1,29 cm menjadi 0,56 $\mathrm{cm}$ atau selisih nilai menurun sebesar $56,9 \%$ atau bisa dikatakan sebagai peningkatan ketelitian sebesar 56,9\%. Peningkatan ketelitian ini akibat adanya penambahan kursi duduk berdiri dan lampu penerangan lokal yang merupakan intervensi ergonomi pada keluhan otot dan kelelahan mata pada mahasiswa praktikan. Dengan penambahan kursi duduk berdiri bisa dilakukan secara dinamis sehingga mengurangi keluhan otot. Penambahan 
penerangan lokal akan menambah jelasnya benda kerja yang diproses dalam praktikum, menambah jelasnya pembacaan pada ukuran benda kerja, dan dapat mengurangi kelelahan mata akibat akomodasi yang terus menerus karena kekurangan cahaya dalam melihat benda kerja.

Intervensi ergonomi dalam hal perbaikan sikap kerja atau stasiun kerja adalah mutlak diperlukan (Manuaba, 1998), karena dengan intervensi ergonomi, misalnya intervensi peralatan yang sesuai antropometri dan sebagainya akan dapat menurunkan beban kerja ataupun keluhan subjektif serta dapat meningkatkan produktivitas kerja (Adiputra dkk., 2000; Azmi dan Marentani, 2001). Rizani dkk (2011) juga menyatakan bahwa kegiatan kerja aplikasi ergonomi akan menjadikan kegiatan kerja menjadi lebih produktif.

Perubahan sikap kerja dan pemberian lampu penerangan lokal ini bisa dilihat pada Gambar 3.1 berikut. 


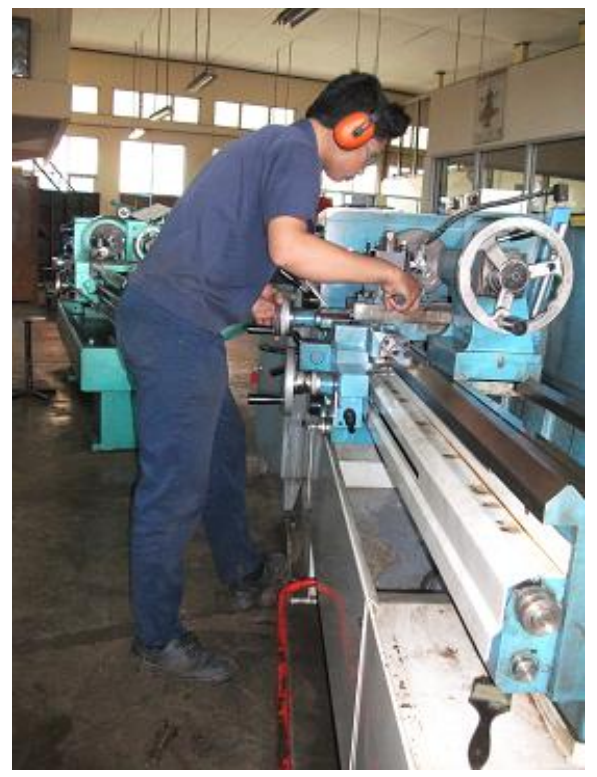

(a)

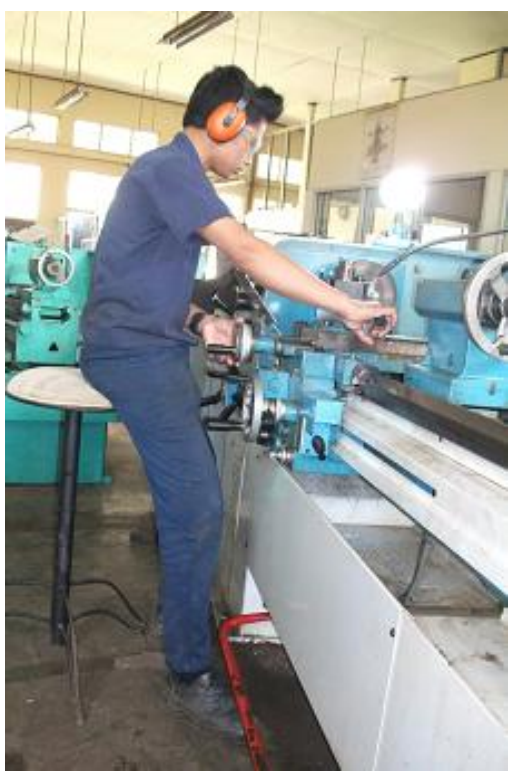

(b)

Gambar 3.1 Sikap Kerja praktikum membubut

(a) Sikap kerja sebelum intervensi ergonomi, (b) Sikap kerja setelah intervensi ergonomi (menggunakan kursi kerja dan penambahan lampu penerangan lokal)

\section{SIMPULAN DAN SARAN}

\subsection{Simpulan}

Bertitik tolak dari hasil analisis dan pembahasan di atas, dapat disimpulkan sebagai berikut.

1. Perbaikan sikap kerja dan penambahan penerangan lokal pada proses pembubutan dapat menurunkan keluhan muskuloskeletal mahasiswa di bengkel mekanik Politeknik Negeri Bali.

2. Perbaikan sikap kerja dan penambahan penerangan lokal pada proses pembubutan dapat menurunkan kelelahan mata mahasiswa di bengkel mekanik Politeknik Negeri Bali.

3. Perbaikan sikap kerja dan penambahan penerangan lokal pada proses pembubutan dapat 
meningkatkan ketelitian hasil

kerja mahasiswa di bengkel

mekanik Politeknik Negeri Bali.

\subsection{Saran}

Dapat dilakukan penelitian lebih lanjut yang lebih mendalam tentang peningkatan kompetensi ditinjau dari proses kerja praktikum pembubutan ataupun praktikum yang lain.

\section{KEPUSTAKAAN}

Adiputra, I N.; Sutjana, I D. P.; Manuaba, I. B. A. 2000. Ergonomics

Intervention in Small Scale Industry in Bali. Dalam : Lim, KY ed. Proceding of the Joint Conference of APCHI and ASEAN Ergonomics, Singapore.

Azmi, N. dan Marentani, M. 2001. Perbaikan Posisi Kerja Mengurangi Keluhan Subjektif gangguan Muskuloskeletal pada Pekerja Helpen di CV PM Bogor. The Indonesian Journal of Ergonomic. Vol.2 No.2
: $67-74$.

Jurusan Teknik Mesin. 2008. Kurikulum Teknik Mesin. Politeknik Negeri Bali.

Manuaba, I. B. A. 1998. Penerangan (Lighting), Dalam Bunga Rampai Ergonomi Volume I. Kumpulan Makalah pada Program Studi Ergonomi-Fisiologi Kerja, Program Pascasarjana. Denpasar : Universitas Udayana.

Petrus, W. dan Rina, S. 2012. Redesain Locker Dosen Dengan Pendekatan Ergonomi. Jurnal Teknologi, Volume 5 Nomor 2, Desember 2012

Rizani, N. C.; Liana, W.; Azmi, N. 2011. Intervensi Ergonomi Untuk Mengurangi Kegiatan Tidak Produktif Pada Stasiun Perakitan PT X. Jurnal Teknologi, Volume 4 Nomor 2, Desember 2011.

Ruccer, L. dan Sunnel, S. 2002. Ergonomic Risk Factors Associated with Clinical Dentistry. Journal of the California Dental Association. Vol.30, 
No.2. available from

Negeri Bali.

http://www.cda.org/me

mber/pubs/journal/jour0

202/2002 CDA Journal

- Feature Article.htm.

Accessed June 20, 2013.

Susetyo, J.; Oesman, T. I.; Sigit, T. S. 2012. Pengaruh Shift Kerja Terhadap Kelelahan Karyawan dengan Metode Bourdon Wiersma dan 30 Item of Rating Scale. Jurnal Teknologi. Volume 5 No.1. Juni 2013.

Sutajaya, I M. dan Citrawathi, D. M. 2000. "Perbaikan Kondisi Kerja Mengurangi Beban Kerja dan Gangguan pada Sistem Muskuloskeletal Mahasiswa dalam menggunakan

Mikroskop di Laboratorium Biologi STKIP Singaraja”. Dalam Wignyo Soebroto, S. \& Wiratno, SE. Eds. Proceedings Seminar nasional Ergonomi. PT. Guna Widya. Surabaya. 239 242.

Tim Lab Mekanik. 2009. Praktek Permesinan dan Las Kerja Bubut 1. Program Studi Teknik Mesin. Denpasar : Politeknik 